\title{
VARIABILITY OF FORAMINIFERAL STABLE ISOTOPE RATIOS IN CARIBBEAN SHALLOW WATERS OF PANAMA: A MODERN FRAMEWORK FOR NEOGENE STUDIES
}

Laurel S. Collins ${ }^{1}$, Dana H. Geary ${ }^{2}$, and Ethan L. Grossman ${ }^{3}$

RRH: PANAMA STABLE ISOTOPES

LRH: L.S. COLLINS ET AL.

${ }^{1}$ Department of Earth and Environment, and Department of Biological Sciences, Florida International University, Miami, Florida 33199, USA; Smithsonian Tropical Research Institute, Box 0843-03092, Balboa, Republic of Panama. Corresponding author: collinsl@ fiu.edu

${ }^{2}$ Department of Geoscience, University of Wisconsin, Madison, Wisconsin 53706, USA.

${ }^{3}$ Department of Geology and Geophysics, Texas A\&M University, College Station, Texas 77843, USA. 


\begin{abstract}
Oxygen and carbon isotope analyses of the foraminifera Orbulina universa (planktic), Uvigerina peregrina (benthic) and Cibicides pachyderma (benthic) in 45 bottom samples from the archipelago of Bocas del Toro, Caribbean Panama, are used to address the reliability of stable isotope values in distinguishing differences among neritic surface water and middle neritic to upper bathyal depths. The significance of variation in isotope values within stations, between stations within depth-defined groups, and between depths was determined with Analysis of Variance. Isotope values differ significantly among stations with few exceptions; thus, withinstation error is minimal. $\delta^{18} \mathrm{O}$ values of $O$. universa across the open shelf are the same. Oxygen isotope ratios of $U$. peregrina discriminate outer shelf to upper slope depths well. $\delta^{18} \mathrm{O}$ values of C. pachyderma from the inner middle shelf, outer middle shelf, and inner outer shelf are significantly different, and mean values from $33 \mathrm{~m}$ to $240 \mathrm{~m}$ are strongly correlated with water depth. Cibicides pachyderma from two stations shows strong $\delta^{18} \mathrm{O}$ evidence of downslope transport of 80 and $160 \mathrm{~m}$, corroborated by foraminiferal assemblages. $\delta^{13} \mathrm{C}$ can only differentiate middle shelf and outermost outer shelf to upper slope depths. Oxygen isotope values of $O$. universa and $U$. peregrina generally agree with predicted temperatures, and those of $C$. pachyderma are consistently low. Comparisons of $\delta^{18} \mathrm{O}$ values of benthic and planktic foraminifera, and neritic and deep-sea planktic foraminifera, enable qualitative and even quantitative estimates of paleodepth and paleosalinity, enabling their use in Neogene studies of sedimentary rocks within the region.
\end{abstract}

Keywords: Foraminifera, Panama, Neritic, Paleoceanography, Analysis of Variance 


\section{Introduction}

The stable isotopes of oxygen and carbon preserved in foraminiferal tests have been widely used to infer changes in paleoceanographic conditions such as temperature, salinity and water composition (e.g., Emiliani, 1955; Shackleton and Opdyke, 1973; Woodruff and Savin, 1989; Haug et al., 2001). Stable isotopes are preferentially applied to deep-sea and open-ocean waters because physical conditions there are more stable than those in shallow and nearshore waters, so that $\delta^{18} \mathrm{O}$ and $\delta^{13} \mathrm{C}$ values more closely approximate a regional or global signal. In recent years, more studies have investigated relationships between neritic marine conditions and stable isotopes of foraminifera. For example, several studies of marginal marine foraminiferal stable isotopes (Ingram et al. 1996a, b; Reinhardt et al., 2003; Eichler et al., 2010, 2014) have established associations of $\delta^{18} \mathrm{O}$ and $\delta^{13} \mathrm{C}$ with salinity, temperature and patterns of freshwater and marine mixing. In neritic and especially nearshore waters, local differences in salinity, temperature, and carbon source can mask regional and global signals, complicating the interpretation of foraminiferal isotopic ratios. However, the neritic setting, rich in macrofossils, is where most evolutionary studies of marine organisms are based. A framework for interpreting neritic stable isotopes would allow better assessment of the impact of environmental change on evolution.

This study examines the correspondence of bathymetry, temperature and salinity to stable

Fig. 1 isotope values in planktic and benthic foraminifera from middle neritic to uppermost bathyal depths of the Bocas del Toro archipelago, Panama, southwestern Caribbean Sea (Fig. 1). We use 
Analysis of Variance (ANOVA) to investigate the variation of isotope values at a station, by testing whether isotopic variability is too great within stations to distinguish between stations, and whether isotopic values vary consistently according to bathymetry on the open shelf or offshore of islands, and to determine the ranges in isotopic values that can be expected at particular depth ranges in the region. The results are also used to investigate the influence of downslope transport on samples across a bathymetric gradient.

The need for a Neogene record of paleoceanographic change tied directly to the evolutionary record of shallow-water faunas of southern Central America motivated this project. The Neogene emergence of the Isthmus of Panama, which caused closure of the Tropical American Seaway connecting Caribbean and eastern Pacific waters, produced dramatic, largescale evolutionary changes (Coates et al., 1992; Collins et al. 1996; Jackson et al., 1996; Collins and Coates, 1999; O’Dea et al., 2007) resulting in part from oceanographic change (Keigwin, 1982; Haug et al., 2001). An isotopic study of Recent foraminifera from Caribbean stations across the continental shelf of western Panama provides a framework for interpreting isotopic values of fossil foraminifera from this and similar tropical settings such as southeast Asia.

\subsection{Study area}

Samples of bottom sediments were collected from the Bocas del Toro archipelago, and the Panama Canal area, all of which are included in ongoing isotopic studies of Neogene foraminifera and mollusks. The archipelago consists of Almirante Bay in the northwest, and the 
more freshwater-influenced Laguna de Chiriquí in the southeast (D’Croz et al., 2005). The region does not experience a clearly defined dry season, but on average, rainfall is less intense during January, March and October (http://worldweather.wmo.int/en/city.html?cityId=1245). Marine productivity is limited by the absence of significant upwelling; however, freshwater input via river discharge into the Laguna de Chiriquí contributes to significant, albeit modest, nutrient influx (D’Croz et al., 2005).

Sedimentation in Bocas del Toro is mixed siliciclastic and carbonate. Erosion of the Cordillera Central on the mainland is rapid in this region of extremely high rainfall (approximately 3 m/yr) and ambient humidity (Rodríguez et al., 1993), resulting in high rates of siliciclastic sedimentation. Rates vary considerably within shallow-water depositional regimes. For example, for the Bahía Almirante, the bay northeast of and adjacent to the Laguna de Chiriquí (Fig. 1), Aronson et al. (2014) used ${ }^{210} \mathrm{~Pb}$ to measure rates of sediment accumulation of $0.7-1.1 \mathrm{~cm} / \mathrm{yr}$. Rates have probably increased in the last 20 years as a result of land development on the larger islands (Guzmán et al. 2005). One might expect sediment accumulation rates in an open-ocean setting to be lower by 1-2 orders of magnitude, on the decadal to centennial scale. Neritic waters support a coral reef ecosystem that produces a large volume of carbonate sediments. The islands and peninsula of Bocas del Toro are composed primarily of fossiliferous Neogene sediments that are a primary source for research on evolution, biogeography, environmental change, and tectonic uplift associated with the emergence of the Isthmus of Panama and closure of the Central American Seaway (Collins, 1993; Jackson et al., 1993; Collins et al., 1995; Teranes et al., 1996; O’Dea et al., 2007; Smith et al. 2013). 
The marine habitats we sampled were (1) offshore of islands (stations 2, 10), (2) in a channel between the lagoon and open continental shelf (station 7), (3) on the open shelf (stations 14, 29-35, 37), and (4) on the uppermost continental slope (stations 36, 38, 40) (Fig. 1, 1). The Laguna de Chiriquí contains low-salinity waters, so the foraminiferal species of interest were not found there (see below). Hydrographic stations sampled by the U.S. Navy provided temperature and salinity data every $10 \mathrm{~m}$ from $0 \mathrm{~m}$ to $\sim 250 \mathrm{~m}$ for different seasons and in years. These stations, mostly located offshore of the area we sampled (Fig. 1; Table 2), give a general idea of the area's water mass structure.

\section{Materials and methods}

Forty-five grab samples of ocean-bottom sediments were collected by the first author at 15 stations (Fig. 1, Table 1) with a Petersen clamshell grab sampler in July 1988 and December 1989 aboard the $R / V$ Benjamin, Smithsonian Tropical Research Institute, Panama. Three replicate samples were taken in separate castings at each station. Surface layers of the sediment were commonly preserved undisturbed in the sampling device. Forty $\mathrm{ml}$ of sediment was removed from the top $6 \mathrm{~cm}$ in a plastic pipe and washed through a $63-\mu \mathrm{m}$ sieve. The top $6 \mathrm{~cm}$ of sediment, the primary living zone for benthic foraminifera (Buzas et al., 1993), is highly bioturbated in well-oxygenated waters, so samples mix living and dead individuals and their isotopic signals from different seasons and/or years. As results of this modern study will ultimately be applied to foraminifera contained in $\sim 50$-g samples of sedimentary rock, the 
mixing of seasons to years in modern samples should approximate the chronologic resolution of the Neogene samples, at an approximately centennial scale.

With few exceptions, at least 25 and commonly > 100 individuals/sample of each of three foraminiferal species (planktic Orbulina universa, and benthic Cibicides pachyderma and Uvigerina peregrina) were picked from washed residues and cleaned of sediment (counts of Table 3). Specimens of Caribbean neritic foraminifera are very small compared with those from deep waters and most other regions. Their diminutive size and calcite loss during washing prevent analyses of samples composed of fewer than about 10 specimens, preventing finer-scaled studies such as that of seasonal change. A relatively large number of specimens/sample is required to obtain a stable mean value from isotope data (Schiffelbein and Hills, 1984) because of large within-sample variability of individuals. Specimens were broken open to clean sediment infilling from chambers, and washed twice in distilled water with an ultrasonic cleaner. We did not analyze all three species from all replicate samples because the species were not found in all samples or, in the case of $O$. universa, we selected only a representative sample set. We analyzed $O$. universa from four stations, U. peregrina from seven stations, and $C$. pachyderma from 14 stations.

Foraminiferal samples of 10 to $1370 \mu \mathrm{g}$ were analyzed in the Stable Isotope Laboratory, University of Michigan. They were roasted at $380^{\circ} \mathrm{C}$ in vacuo for $1 \mathrm{hr}$ to remove volatile contaminants, placed in individual borosilicate reaction vessels, and reacted with phosphoric acid at $73^{\circ} \mathrm{C}$ on a Finnigan Kiel automated carbonate device. This system is coupled directly to the 
inlet of a Finnigan MAT 251 isotope ratio mass spectrometer. After correction for acid fractionation and ${ }^{17} \mathrm{O}$ contributions, isotopic enrichments were converted to the PDB scale and normalized to the best-fit linear regression line defined by NBS-18 and NBS-19 standards. Data precision was monitored through daily analysis of six NBS standards per run. Replicate analyses of standards indicated a precision of $\pm 0.08 \%$ PDB for $\delta^{18} \mathrm{O}$ and $\pm 0.05 \%$ PDB for $\delta^{13} \mathrm{C}$.

With Analysis of Variance (ANOVA), we determined the statistical significance of variation in isotope values between replicate samples at a station, between stations, and between environments defined by water depth (e.g., outer shelf). Ideally, for application to paleoenvironmental studies, isotopic values should be the same within environments but different between environments. The $F$ test that results from an ANOVA tests the null hypothesis that the means in a group are all equal, and a probability $p$ of whether groups are significantly different from each other is calculated. This test does not indicate which means are significantly different from other means, so we also performed posthoc pairwise tests of significant differences in the means of depth-defined environments. F tests of hypotheses about contrasts across environmental means are based on the A matrix, which is created by a linear combination of means and coefficients that are selected to contrast the means and that sum to 0 . We used SYSTAT v. 5.02 computer programs for all computations (Systat, 1992).

\section{Foraminiferal ecology and stable isotope geochemistry}

Three foraminiferal species were selected for isotopic analysis based on their fossil to 
Recent abundance and reliability of their stable isotopic compositions as environmental indicators (e.g., Zahn et al., 1986; Bartoli et al., 2005). To evaluate surface-water conditions, we used planktic Orbulina universa d'Orbigny, which secretes its calcite test in upper surface waters $<75 \mathrm{~m}$ deep within the euphotic zone (Fairbanks et al., 1982). In the tropical Atlantic, the depth distribution of this species peaks at $25-35 \mathrm{~m}$ based on core-top $\delta^{18} \mathrm{O}$ data (Farmer et al., 2007). Even if it migrates later to greater depth, $O$. univers $a$ apparently calcifies only within the mixed layer (Bouvier-Soumagnac and Duplessy, 1985). Isotope values reflect a very small range of temperature per individual because its spherical chamber, which is $90-95 \%$ of the total test calcite, is secreted during the final 3-5 days of its life (Caron et al., 1987; Spero, 1988). Previous studies show that $O$. universa secretes calcite close to oxygen isotopic equilibrium with seawater as defined by Epstein et al. (1953) (Bouvier-Soumagnac and Duplessy, 1985; Bemis et al., 1998). For the temperature range of $O$. universa in this study, $16-27^{\circ} \mathrm{C}$, isotopic temperatures calculated with the low-light equation of Bemis et al. (1998), based on culture experiments, differ from those of the Epstein et al. (1953) equation by only $0.0-0.4^{\circ} \mathrm{C}$, respectively. Another factor to consider is gametogenic calcification, which can add ${ }^{18} \mathrm{O}$-enriched calcite later in the species' ontogeny (e.g., Bé, 1980). Orbulina universa tracks changes in the carbon isotopic composition of seawater in which it grows, with minor effects from respiration (Spero et al., 1991) and water temperature (Bouvier-Soumagnac and Duplessy, 1985; Spero and DeNiro, 1987; Spero and Williams, 1988), so that major $\delta^{13} \mathrm{C}$ differences should reflect changes in the $\delta^{13} \mathrm{C}$ of seawater $\Sigma \mathrm{CO}_{2}$. which will decrease with depth (Kroopnick, 1985) and mixing with fresh water (Graniero et al., 2016). 
We analyzed the benthic foraminifera Uvigerina peregrina Cushman (sensu Poag, 1981) and Cibicides pachyderma Rzehak (sensu van Morkhoven et al., 1986) to determine bottom stable isotopic values. It has been demonstrated to be relatively free of "vital effects" (Shackleton, 1973; Grossman, 1984, 1987), depositing its test in isotopic equilibrium with ambient conditions for $\delta^{18} \mathrm{O}$, and with a $1 \%$ offset for $\delta^{13} \mathrm{C}$ (Smith and Emiliani, 1968; Shackleton, 1977; Woodruff et al., 1980; Graham et al., 1981; Ganssen, 1983; Dunbar and Wefer, 1984). Graham et al. (1981) show that the oxygen isotope equilibrium fractionation of this taxon has remained constant through time. Uvigerina peregrina's shallow infaunal habitat translates to carbon isotopic values that reflect shallow porewaters instead of bottom waters (Zahn et al., 1986; Corliss and Emerson, 1990; McCorkle et al., 1990, 1997). Rather than being constrained to a specific subsurface depth, foraminifera appear to seek preferred redox or feeding microhabitats. They occupy shallow burial depths in organic-rich, oxygen-poor sediments, and deeper burial depths in more oxygenated, organic-poor sediments. In more chemically heterogeneous subsurface environments created by bio-irrigation of burrowing invertebrates, a heterogeneous distribution prevails (e.g., McCorkle et al., 1990; Loubere et al., 1995; Rathburn et al., 1995; McCorkle et al., 1997; Loubere et al., 2011).

Benthic Cibicides pachyderma provides an epifaunal contrast to the shallow infaunal $U$. peregrina. Lutze and Thiel (1989) reported that Cibicides individuals actively choose elevated habitats that expose them directly to bottom waters. McCorkle et al. (1997) observed that both $U$. peregrina and $C$. pachyderma typically show maximum abundances at or immediately below the sediment-water interface, but $C$. pachyderma abundance decreases more quickly with depth, 
suggesting an epifaunal habitat in contrast to the shallow infaunal habitat of $U$. peregrina.

The $\delta^{13} \mathrm{C}$ of Cibicides is generally close to that of bottom-water total dissolved inorganic carbon, and it faithfully records regional variations in bottom-water $\delta^{13} \mathrm{C}$ (e.g., Graham et al., 1981; Duplessy et al., 1988, McCorkle et al., 1990), although Mackensen et al. (1993) show that Cibicides $\delta^{13} \mathrm{C}$ is affected by sediment organic carbon. Cibicides pachyderma has been used in deep-sea isotopic studies of climate change associated with closure of the Isthmus of Panama seaway (e.g., Bartoli et al., 2005). General bathymetric trends in isotope values of cibicidids and uvigerinids from the same shallow-water samples might be expected to be correlated (but see McCorkle et al., 1997). Zahn et al. (1986) demonstrate a possible microhabitat effect on $\delta^{13} \mathrm{C}$ of $U$. peregrina based on (nonlinear) correlation with carbon accumulation, although their data show that the $\delta^{13} \mathrm{C}$ of $U$. peregrina is also correlated with the $\delta^{13} \mathrm{C}$ of $C$. wuellerstorfi, which is a good indicator of ambient bottom-water $\delta^{13} \mathrm{C}$.

\section{Results and discussion}

All values of $\delta^{18} \mathrm{O}$ and $\delta^{13} \mathrm{C}$ are given in Table 3 and Figure 2. Nearly all stations have three replicate values per station. The number of specimens analyzed per sample (counted before being broken open for removal of infilling) averaged 54 for Orbulina universa, 141 for Uvigerina peregrina, and 127 for Cibicides pachyderma. Predicted $\delta^{18} \mathrm{O}$ values were calculated using the paleotemperature equation of Epstein et al. (1953) as reported by Grossman (2012): 


$$
\mathrm{T}=16.5-4.3\left(\delta^{18} \mathrm{O}_{\mathrm{c}}-\delta^{18} \mathrm{O}_{\mathrm{w}}+0.27\right)+0.14\left(\delta^{18} \mathrm{O}_{\mathrm{c}}-\delta^{18} \mathrm{O}_{\mathrm{w}}+0.27\right)^{2},
$$

where seawater $\delta^{18} \mathrm{O}\left(\delta^{18} \mathrm{O}_{\mathrm{w}}\right)$ is reported versus VSMOW. $\delta^{18} \mathrm{O}_{\mathrm{w}}$ was determined using temperature and salinity profiles, and the relationship between $\delta^{18} \mathrm{O}_{\mathrm{w}}$ and salinity for southwest Caribbean (Tao et al., 2013):

$$
\delta^{18} \mathrm{O}_{\mathrm{w}}(\%)=0.19( \pm 0.03) \mathrm{S}(\mathrm{psu})-5.75( \pm 0.87) .
$$

$\delta^{18} \mathrm{O}$ increases with depth as expected (Fig. 2, plotted negative to the right), for the foraminifera as well as Conus gastropods (Tao et al., 2013).

Although Bocas del Toro does not experience a pronounced dry season like that of Pacific Panama, modest seasonality in rainfall does occur (Kauffman and Thompson 2005) and could result in variability in foraminiferal $\delta^{18} \mathrm{O}$. This seasonality is recorded in the $\leq 1.0 \%$ range of $\delta^{18} \mathrm{O}$ in serially-sampled Conus gastropod shells from $<50 \mathrm{~m}$ depth off Bocas del Toro and in the adjacent Golfo de los Mosquitos to the east (Tao et al., 2013). The Conus variability is much less than the variability seen in the within-station foraminiferal data, which extend $200 \mathrm{~m}$ deeper. Since temperature variation is minimal, the $\delta^{18} \mathrm{O}$ variation in Conus is interpreted as seasonal variation in salinity and thus $\delta^{18} \mathrm{O}_{\mathrm{w}}$. However, the lack of a significant intrashell $\delta^{18} \mathrm{O}-\delta^{13} \mathrm{C}$ correlation in Conus suggests no simple relationship between freshwater input and $\delta^{13} \mathrm{C}$ in this region.

\subsection{Orbulina universa}

We expected similar, geographically and temporally averaged values of $\delta^{18} \mathrm{O}$ and $\delta^{13} \mathrm{C}$ from $O$. universa for all analyzed stations, because planktic species are transported many 
kilometers in several days, and bottom-sediment samples reflect signals mixed from different seasons and years. Four channel to open-ocean stations were analyzed: 7 (56 m), 14 (90 m), 31 $(168 \mathrm{~m})$ and $40(240 \mathrm{~m})$. Specimens were rare at station 7 (56 m, Fig. 1) in the Tiger Channel so replicates were combined to yield enough sample for analysis. Surface-water $\delta^{18} \mathrm{O}$ appears to be relatively invariant across the open shelf (Figs. 2, 3A). The lower value for the channel probably reflects the outflow of less saline waters from the lagoon into the open-ocean (D'Croz et al., 2005). The $\delta^{18} \mathrm{O}$ values of $O$. universa are consistent with a depth habitat of about $30 \mathrm{~m}$ (Fig. 2), in agreement with plankton tow (Fairbanks et al., 1982) and core-top (Farmer et al., 2007) data. Lack of gametogenic calcification could explain the lower $\delta^{18} \mathrm{O}$ values for the shallowest samples, although non-gametogenic calcite should have $\delta^{18} \mathrm{O}$ values closer to predicted values. Also, we might expect increasing $\delta^{18} \mathrm{O}$ with increasing depth and thus increasing potential for deeper gametogenic calcification. Lohmann (1985) presents evidence that at least in Globigerinoides sacculifer, most gametogenic calcification occurs in or just below the mixed layer. If also true for $O$. universa, then gametogenic calcite, which has been found to comprise up to $\sim 20 \%$ of the test (Hamilton et al., 2008), would have a minimal effect on $\delta^{18} \mathrm{O}$.

Excluding the channel sample (station 7), the $\delta^{18} \mathrm{O}$ average of $-1.35 \pm 0.07 \%$ is $0.32 \%$ lower than open-ocean O. universa from tropical Atlantic core-tops (Farmer et al., 2007). This suggests that the Bocas del Toro specimens are recording salinities 1-2 psu lower than those of the open ocean away from coastlines, based on equation 1 (above). There are no apparent bathymetric or geographic trends for $\delta^{13} \mathrm{C}$. 
Results of one-way ANOVAs (Tables 4, 5) support these observations. Low probabilities (p) for the $\delta^{18} \mathrm{O}$ and $\delta^{13} \mathrm{C}$ all-stations tests indicate overall significant differences in isotope values between stations. For $\delta^{18} \mathrm{O}$, this difference is due to the disparate channel value (station 7). A one-way ANOVA for $\delta^{18} \mathrm{O}$ that excludes the channel outlier results in a high $p$ value of 0.941 and a very low variance (mean square) of $<0.0005$, which indicate no real difference between open-shelf stations. $\Delta^{13} \mathrm{C}$ is significantly different between stations; we note a possible geographic component of higher values for Escudo de Veraguas stations (90 m and 240 m, Fig. 3A).

\subsection{Uvigerina peregrina}

There is excellent correspondence between predicted and measured $\delta^{18} \mathrm{O}$ values of $U$. peregrina (Fig. 2). Within-station variability in $\delta^{18} \mathrm{O}$ and $\delta^{13} \mathrm{C}$ is very low (maxima $=0.15 \%$ for $\delta^{18} \mathrm{O}$ at site $34,0.24 \%$ for $\delta^{13} \mathrm{C}$ at site 38$)$ for seven stations $(30,31,34,35,36,38,40)$ across the outer shelf to upper slope (Fig. 3B). $\delta^{18} \mathrm{O}$ shows a strong linear correlation with water depth ( $r=0.964, p<0.0005$ ) because of decreasing temperatures (from $\sim 22^{\circ} \mathrm{C}$ at $120 \mathrm{~m}$ to $\sim 15^{\circ} \mathrm{C}$ at $240 \mathrm{~m}$; Table 2).

A one-way ANOVA of $\delta^{18} \mathrm{O}$ values for all seven $U$. peregrina stations (Table 4) indicates that stations are different overall. In a nested ANOVA of $\delta^{18} \mathrm{O}$ data, we used the $120 \mathrm{~m}, \sim 165 \mathrm{~m}$, and $\sim 240 \mathrm{~m}$ depths as three distinct environmental groups to evaluate differences compared with the variability within stations. (The single 180-m station was excluded because more than one station is necessary to assess station variability within groups.) Nested ANOVA results (Tables 
$4,6)$ indicate that stations within bathymetric groups are the same and environments are different with no geographic effect.

ANOVAs test the hypothesis that all means are equal, but they do not address which groups are different from the others or how different they are. After estimating the ANOVA model, we examined which bathymetric groups are significantly different from each other for $U$. peregrina with a series of post-hoc, pairwise A matrix contrasts. In all cases of contrasting the bathymetries (120 m vs. $165 \mathrm{~m}, 120 \mathrm{~m} v s .240 \mathrm{~m}$, and $165 \mathrm{~m} v s .240 \mathrm{~m}), p<0.0005$, so all bathymetric groups have significantly different $\delta^{18} \mathrm{O}$ values.

In contrast to $\delta^{18} \mathrm{O}$, values of $\delta^{13} \mathrm{C}$ for $U$. peregrina are not good at discriminating these bathymetric groups. There is a weak positive correlation of $\delta^{13} \mathrm{C}$ with water depth (Fig. 3B), but the shallowest and deepest values overlap significantly. Although the nested ANOVA results (Table 4) show bathymetric groups to be different, stations within the groups are also significantly different. These results agree with isotopic studies of live-stained benthic foraminifera collected elsewhere at different sediment depths in box cores that show little intracore $\delta^{13} \mathrm{C}$ variation with depth for infaunal species, but significant differences between infaunal and epifaunal species (e.g., Cibicidoides [Cibicides]) reflecting differences in depth habitat (McCorkle et al., 1997). We conclude that $\delta^{13} \mathrm{C}$ in Uvigerina cannot discriminate bathymetries. 


\subsection{Cibicides pachyderma}

$\delta^{18} \mathrm{O}$ vs. $\delta^{13} \mathrm{C}$ was examined for 14 stations $(2,7,10,14,29-35,37,38,40)$ across the middle shelf to upper slope, 33-240 m deep (Fig. 3C). Habitats include channel, island, and open-ocean (Fig. 1). With the exceptions of one 90-m replicate (far right) and the 56-m channel station, variability between replicates at a station is small.

In general, the $\delta^{18} \mathrm{O}$ values of $C$. pachyderma are correlated with increasing water depth and thus, decreasing temperature (from $\sim 27^{\circ} \mathrm{C}$ at $33 \mathrm{~m}$ to $\sim 15^{\circ} \mathrm{C}$ at $230 \mathrm{~m}$; Table 2 ). We surmise that the low $\delta^{18} \mathrm{O}$ values of Cibicides from stations $38(164 \mathrm{~m})$ and $40(240 \mathrm{~m})$ result from downslope transport, as evidenced by the large $\delta^{18} \mathrm{O}$ difference between Cibicides and Uvigerina $\left(\Delta^{18} \mathrm{O}_{\text {Cib-Uvig }}<<-0.4 \%\right)$. Carbon isotopes provide further evidence for downslope transport, as Cibicides from stations 38 and 40 have unusually high $\delta^{13} \mathrm{C}$ values typical of specimens shallower than $120 \mathrm{~m}$. We can calculate the vertical and lateral displacement based on the $\delta^{18} \mathrm{O}$ of Cibicides from stations 38 and 40 . Values of about $-1.2 \%$ o suggest transport from about $80 \mathrm{~m}$ depth and lateral displacement of roughly $3 \mathrm{~km}$ or more (Figs. 1, 2).

The composition of the whole foraminiferal assemblages (Havach and Collins, 1997) originally identified the downslope transport confirmed (above) by these stable isotopes. Samples from stations $37(113 \mathrm{~m}), 38(164 \mathrm{~m})$ and $40(240 \mathrm{~m})$ contain deeper-dwelling, dominantly outer shelf - upper slope species such as Cassidulina curvata, Gyroidina regularis, G. turgida, G. umbonata and Uvigerina laevis, together with taxa that are most abundant on the shallow middle shelf such as Amphistegina gibbosa, Biloculinella eburnea, Cornuspira 
planorbis, Hauerina fragilissima, Laevepeneroplis proteus/carinatus, Neoconorbina terquemi, Nodobaculariella cassis and Textularia schencki. There is no indication of a bimodal distribution in preservation state that would indicate reworking of significantly older specimens, which would not be predicted anyway with the estimated high rates of sedimentation. The assemblages also have a diversity nearly twice that of other sampled stations (as measured with the diversity index Fisher's alpha; Collins, 1999), an expectation of mixed assemblages (Havach and Collins, 1997). Uvigerina peregrina is rare in shallower (<120 m) samples; thus, downslope transport is less likely to influence their isotopic signal in deeper samples. Alternatively, the infaunal specimens may be less likely to experience redeposition by sedimentary processes such as gravity flows down relatively steep inclines surrounding Escudo de Veraguas island that are the most likely cause of the redeposition.

We tested carbon and oxygen isotopic variability in C. pachyderma between stations, both within and between bathymetric groups. The samples of transported sediments (stations 37, 38 , 40; see above) were excluded, thereby eliminating replicates for 168-240 m depths, so stations were placed in groups for $35 \mathrm{~m}$ ( 2 samples), $\sim 80 \mathrm{~m}$ ( 3 samples: $73 \mathrm{~m}, 80 \mathrm{~m}, 90 \mathrm{~m}$ ), and $120 \mathrm{~m}$ (2 samples). In nested ANOVAs of $\delta^{18} \mathrm{O}$ and $\delta^{13} \mathrm{C}, p$ values (Tables 4, 7) indicate overall Table 7 significant differences between water depths and between sites within bathymetric groups. Posthoc pairwise contrasts for the $\delta^{18} \mathrm{O}$ ANOVA show that $\delta^{18} \mathrm{O}$ values of $C$. pachyderma from the groups at $35 \mathrm{~m}, \sim 80 \mathrm{~m}$, and $120 \mathrm{~m}$ are significantly different from each other $(p<0.0005)$.

The fact that the ANOVAs indicate a significant difference between sites within 
environments might initially suggest that Cibicides pachyderma at these depths would not be a useful paleoenvironmental tool, but examination of the variance for $\delta^{18} \mathrm{O}$ means and the station means themselves show otherwise. The proportion of between-environments variance (i.e., the mean square, 1.258) is an order of magnitude greater than the variance attributed to the difference between stations within environments (0.155) (Table 7). This signifies a much better differentiation of environments than stations within environments. Most of the variance in stations within environments is attributed to variability in average values within the $\sim 80 \mathrm{~m}$ group (Table 3), including an outlier replicate value of -0.40 at the $90-\mathrm{m}$ station (Fig. 3). Another complication is the relatively extreme variability in $\delta^{18} \mathrm{O}$ shown by the $56-\mathrm{m}$ station (Fig. 3) located in the channel where lagoon and open-shelf waters mix, also an outlier in the $O$. universa analyses. Despite these complications, there is a highly correlated, linear increase in $\delta^{18} \mathrm{O}$ of $C$. pachyderma $(r=0.976, p \leq 0.0005)$ from middle neritic to upper bathyal depths (Table 8$)$.

The $\delta^{13} \mathrm{C}$ values of $C$. pachyderma generally decrease with increasing depth, in accordance with the expected decrease in the $\delta^{13} \mathrm{C}$ of seawater DIC (total dissolved inorganic carbon). However, stations and bathymetric groups overlap considerably in $\delta^{13} \mathrm{C}$ values (Fig. 3C). $\delta^{13} \mathrm{C}$ values differentiate only middle shelf $(33-90 \mathrm{~m})$ from outermost outer shelf to upper slope (168-230 m) and do not record finer scale differences. There may also be some geographic effect shown by stations from the Escudo de Veraguas area (Fig. 1) at 35, 90, 113, 164 and 240 $\mathrm{m}$, which have the highest $\delta^{13} \mathrm{C}$ values. Samples of $O$. universa also have their highest values from the Escudo de Veraguas area. 


\section{4. $\delta^{18} \mathrm{O}$ Values and temperature}

Oxygen isotope values obtained for Orbulina universa generally agree with predicted values (Fig. 2). The variability in $\delta^{18} \mathrm{O}$ of the shallowest 56-m samples is within the seasonal variability recorded in Conus shells from Bocas del Toro (16 m) and Golfo de los Mosquitos (41 m). Substituting $\delta^{18} \mathrm{O}_{\mathrm{w}}=0.81 \%$, and $\delta^{18} \mathrm{O}_{\mathrm{c}}=-1.25 \%$ to $-1.50 \%$ (the range of open-shelf values for $O$. universa) yields temperatures between $26.0^{\circ}$ and $27.2^{\circ} \mathrm{C}$, which agree well with measured temperatures (Table 2).

As in many other studies (e.g., Grossman, 1987; McCorkle et al., 1997), $\delta^{18} \mathrm{O}$ values of Uvigerina peregrina approximate equilibrium values, while those of Cibicides are low for deeper waters (Fig. 2). Using equation (1) and $\delta^{18} \mathrm{O}$ values of $U$. peregrina to calculate expected temperatures for $120 \mathrm{~m}$ and $240 \mathrm{~m}$, we obtain mean temperatures of $22.8^{\circ} \mathrm{C}$ and $16.5^{\circ} \mathrm{C}$, respectively, which agree well with measured values (Table 2). Temperature calculations using $\delta^{18} \mathrm{O}$ values of $C$. pachyderma, corrected by $+0.31 \pm 0.11 \%$ to account for $U$. peregrina-C. pachyderma differences, yield $26.4^{\circ} \mathrm{C}$ for $33 \mathrm{~m}$ and $17.4^{\circ} \mathrm{C}$ for $230 \mathrm{~m}$ (Table 2).

Determining Neogene paleoenvironments from $\delta^{18} \mathrm{O}$ data of neritic foraminifera must take into account multiple influences and limited constraints on the data such as the lack of knowledge of seawater $\delta^{18} \mathrm{O}$. Isotopic records of bottom temperatures are influenced by the paleobathymetry (with deeper waters being colder) and potential downslope transport that could mix specimens from different depths. Determination of paleosalinity change requires knowledge of temperature or constant temperature. Despite these limitations, supplementary data help 
constrain the system and, at minimum, provide relative changes in paleosalinity and/or paleobathymetry. For example, $\delta^{18} \mathrm{O}$ differences between planktic and benthic foraminifera, which record surface-bottom temperature and salinity contrasts, can be used as paleobathymetric indicators, assuming surface-bottom differences vary systematically with water depth, if (1) samples are screened for downslope transport based on foraminiferal assemblages, (2) taxonomic differences in $\delta^{18} \mathrm{O}$ are constant and understood, and (3) coeval $\delta^{18} \mathrm{O}$ values from deep-sea foraminifera are incorporated.

The $\delta^{18} \mathrm{O}_{\text {Cibicides }}-\delta^{18} \mathrm{O}_{\text {Orbulina }}$ contrast increases with water depth (Fig. 4, stations 7, 14, 31). This relationship has the potential to provide quantitative measures of paleobathymetry, although overestimates could result from unusually low-salinity surface waters. Comparison between $\delta^{18} \mathrm{O}$ data for local Orbulina and deep-sea Orbulina $\left(\Delta^{18} \mathrm{O}_{\text {OrbL-OrbD }}\right)$ from cores (or core-tops in the case of modern specimens) provides a test for unusually low coastal salinities. If constant tropical temperatures are assumed, salinity differences can be calculated from $\Delta^{18} \mathrm{O}_{\text {OrbL-OrbD }}$ using the slope in Equation 2. Deeper offshore samples yield coastal freshening of 1-2 psu (Fig. 4), as discussed earlier, whereas the shallowest, most nearshore, 56-m sample (station 7) yields salinities 5 psu lower (roughly 31-32 psu). Given the salinity data of D'Croz et al. (2005) and the extremely high annual rainfall in Bocas del Toro, with a mean of $3277 \mathrm{~mm}$ and range of 2000$4500 \mathrm{~mm}$ for 1972 - 2003 (Kaufmann and Thompson 2005), these calculated salinities appear reasonable for rainy months when nutrient levels are highest. Tao et al. (2013) proposed a similar baseline approach comparing $\delta^{18} \mathrm{O}$ data for serially-sampled Conus shells with data from openocean planktic foraminifera, and Robbins et al. (2012) demonstrated the approach in fossil shells. 
This application of oxygen isotopes to determining paleobathymetry and paleosalinity could be further refined with the addition of foraminiferal $\mathrm{Mg} / \mathrm{Ca}$ paleothermometry (e.g., Lea et al., 2000; Lear et al., 2000).

\section{Conclusions}

Analysis of variance (ANOVA) for modern samples quantifies the reliability of stable isotopes of Neogene foraminifera for distinguishing paleobathymetries, which reflect temperature and seawater composition. Stable isotope plots reveal general bathymetric trends, convey information about stable isotope trends vs. bathymetric trends, and indicate overlapping values for different depths. ANOVAs identify situations in which nonoverlapping values from different depths are variable enough that differences in isotopes for those depths are not considered significant. The results for Bocas del Toro, Panama are as follows:

a. Similar values of $\delta^{18} \mathrm{O}$ for open-shelf Orbulina universa indicate homogeneity of average upper surface-water temperatures and salinities across the outer shelf.

b. Isotope values of Uvigerina peregrina and Cibicides pachyderma differ significantly between all stations so within-station error was minimal at $33-240 \mathrm{~m}$.

c. $\quad \delta^{18} \mathrm{O}$ values of $U$. peregrina distinguish depths from $120-240 \mathrm{~m}$ very well. $\delta^{13} \mathrm{C}$ does not distinguish these depths.

d. $\quad \delta^{18} \mathrm{O}$ values of $C$. pachyderma differ significantly for $35 \mathrm{~m}, \sim 80 \mathrm{~m}$ and $120 \mathrm{~m}$. The mean $\delta^{18} \mathrm{O}$ per station is strongly correlated with depths from $33-230 \mathrm{~m} . \delta^{13} \mathrm{C}$ differentiates only middle shelf (33-90 m) and outermost outer shelf to upper slope (168-230 m). 
e. $\quad \delta^{18} \mathrm{O}$ values of $O$. universa and $U$. peregrina generally agree with temperatures predicted from an equation. Those of $C$. pachyderma are low for deeper neritic waters. The offset in values between the benthic species increases consistently with depth.

f. Downslope transport of middle-shelf $C$. pachyderma result in lower $\delta^{18} \mathrm{O}$ values than for $U$. peregrina. Downslope transport is also indicated by higher $\delta^{13} \mathrm{C}$ values. The stable isotope patterns agree with mixing of outer shelf-upper slope and shallow middle-shelf assemblages (Havach and Collins, 1997). Based on C. pachyderma $\delta^{18} \mathrm{O}$ values, specimens were transported $\sim 80-160$ m deeper.

We conclude that oxygen isotope differences in coeval benthic $U$. peregrina and $C$. pachyderma, and planktic $O$. universa, can serve as paleodepth and paleosalinity indicators in these tropical neritic settings, and these relationships can be applied within the limits described above (a.-f.) to studies of Neogene sedimentary rocks of Bocas del Toro, Panama (Collins 1993, Coates et al. 2003). The approach requires screening for downslope transport using the preferred depth ranges of benthic foraminifera, and referencing neritic $\delta^{18} \mathrm{O}$ data to complementary planktic foraminiferal data from deep-sea cores.

\section{Acknowledgments}

We are grateful to the Smithsonian Tropical Research Institute (STRI), Panama, for shiptime on the $R / V$ Benjamin and Captain David West's positioning skills. We thank K. C Lohmann's Stable Isotope Laboratory, University of Michigan, for the analyses. Shen Mei, Brian 
Bodenbender, Diane Ritchey and Erin Wilson prepared foraminiferal samples. Lora Wingate ran isotopic analyses, and Bonnie Miljour prepared the map. Comments by William Anderson, Enriqueta Barrera, Martin Buzas, Lee-Ann Hayek, G. P. Lohmann, Christina Ravelo and Divya Saxena greatly improved the paper's quality. This research was supported by a STRI postdoctoral fellowship to Collins and National Science Foundation grants EAR-9304654 and EAR-1325683.

\section{References}

Aronson, R.B., Hilbun, N.L., Bianchi, T.S., Filley, T.R., McKee, B.A., 2014. Land use, water quality, and the history of coral assemblages at Bocas del Toro, Panamá. Mar. Ecol. Prog. Ser. 504, 159-170, doi: 10.3354/meps10765.

Bartoli, G., Sarnthein, M., Weinelt, M., Erlenkeuser, H., Garbe-Schonberg, D., Lea, D.W., 2005. Final closure of Panama and the onset of northern hemisphere glaciation. Earth Planet. Sci. Lett. 237, 33-44.

Bouvier-Soumagnac, Y., Duplessy, J.-C., 1985. Carbon and oxygen isotopic composition of planktonic foraminifera from laboratory culture, plankton tows and Recent sediment: implications for the reconstruction of paleoclimatic conditions and of the global carbon cycle. Journal of Foraminiferal Research 15, 302-320.

Buzas, M.A., Culver, S.J., Jorissen, F.J., 1993. A statistical evaluation of the microhabitats of living (stained) infaunal benthic foraminifera. Marine Micropaleontology 20, 311-320.

Caron, D.A., Faber, Jr., W.W., Bé, A.W.H., 1987. Growth of the spinose planktonic foraminifer 
Orbulina universa in laboratory culture and the effect of temperature on life processes. Journal of the Marine Biological Association, United Kingdom 67, 343-358.

Coates, A.G., Jackson, J.B.C., Collins, L.S., Cronin, T.M., Dowsett, H.J., Bybell, L., Jung, P., Obando, J.A., 1992. Closure of the Isthmus of Panama: the near-shore marine record of western Panama and Costa Rica. Geological Society of America, Bulletin 104, 814-828.

Coates, A.G., Aubry, M.-P., Berggren, W.A., Collins, L.S., Kunk, M., 2003. Early Neogene history of the Central American arc from Bocas del Toro, western Panama. Geol. Soc. Am. Bull. 115, 271-287.

Collins, L.S., 1993. Neogene paleoenvironments of the Bocas del Toro Basin, Panama. Journal of Paleontology 67, 699-710.

Collins, L.S., 1999. The Miocene to Recent diversity of Caribbean benthic foraminifera from the Central American isthmus. In: Collins, L.S., and Coates, A.G. (Eds.), A Paleobiotic Survey of Caribbean Faunas from the Neogene of the Isthmus of Panama. Bulletins of American Paleontology 357, 92-107.

Collins, L.S., Budd, A.F., Coates, A.G., 1996. Earliest evolution associated with closure of the Tropical American Seaway. Proc. Natl. Acad. Sci. 93, 6069--6072.

Collins, L.S., Coates, A.G. (Eds.), 1999. A Paleobiotic Survey of Caribbean Faunas from the Neogene of the Isthmus of Panama. Bulletins of American Paleontology, 351pp.

Collins, L.S., Coates, A.G., Jackson, J.B.C., Obando, J.A., 1995. Timing and rates of emergence of the Limón and Bocas del Toro basins: Caribbean effects of Cocos Ridge subduction? In: Mann, P. (Ed.), Geologic and Tectonic Development of the Caribbean Plate Boundary in southern Central America, Geol. Soc. Am. Spec. Pap. 295, 263-289. 
Corliss, B.H., Emerson, S.R., 1990. Distribution of rose Bengal stained deep-sea benthic foraminifera from the Nova Scotian continental margin and Gulf of Maine. Deep-Sea Res. 37, 381-400.

Craig, H., Gordon, L.I., 1965. Deuterium and oxygen 18 variations in the ocean and the marine atmosphere In: Tongiorgi, E. (Ed.), Stable Isotopes in Oceanographic Studies and Paleotemperatures. Consiglio Nazionale delle Ricerche, Laboratorio di Geologia Nucleare, Pisa, 9-130.

D'Croz, L., Del Rosario, J.B., Gondola, P., 2005. The effect of fresh water runoff on the distribution of dissolved inorganic nutrients and plankton in the Bocas del Toro archipelago, Caribbean Panama. Carib. J. Sci. 41, 414-429.

Dunbar, R.B., Wefer, G., 1984. Stable isotope fractionation in benthic foraminifera from the Peruvian continental margin. Marine Geology 59, 215-225.

Duplessy, J.C., Shackleton, J.J., Fairbanks, R.G., Labeyrie, L., Oppo, D., Kallel, N., 1988. Deep water source variations during the last climatic cycle and their impact on the global deep water circulation. Paleoceanography 3, 317-360.

Eichler, P.P.B., Billups, K., Cardona, C.C.V., 2010. Investigating faunal and geochemical methods for tracing salinity in an Atlantic coastal lagoon, Delaware, USA. Journal of Foraminiferal Research 40, 16-35.

Eichler, P.P.B., Billups, K., Vital, H., de Moraes, J.A., 2014. Tracing thermohaline properties and productivity of shelf-water masses using the stable isotopic composition of benthic foraminifera. Journal of Foraminiferal Research 44, 352-364.

Emiliani, C., 1955. Pleistocene temperatures. J. Geol. 63, 538-578. 
Epstein, S., Buchsbaum, Lowenstam, H., Urey, H.C., 1953. Revised carbonate-water isotopic temperature scale. Geol. Soc. Am. Bull. 64, 1315-1326.

Epstein, S., Mayeda, T., 1953. Variation of $\mathrm{O}^{18}$ content of waters from natural sources, Geochimica et Cosmochimica Acta 4, 213-224.

Fairbanks, R.G., Sverdlove, M., Free, R., Wiebe, P.H., Bé, A.W.H., 1982. Vertical distribution and isotopic fractionation of living planktonic foraminifera from the Panama Basin. Nature 298, 841-844.

Farmer, E.C., Kaplan, A., de Menocal, P.B., Lynch-Stieglitz, J., 2007. Corroborating ecological depth preferences of planktonic foraminifera in the tropical Atlantic with the stable oxygen isotope ratios of core top specimens. Paleoceanography 22, DOI: 10.1029/2006PA001361.

Ganssen, G., 1983. Dokumentation von küstennahem Auftrieb anhand stabiler Isotope in rezenten Foraminiferen vor Nordwest-Afrika, "Meteor" Forschungs-Ergebnisse, C 37, 146.

Graham, D.W., Corliss, B.H., Bender, M.L., Keigwin, L.D., Jr., 1981. Carbon and oxygen isotopic disequilibria of Recent deep-sea benthic foraminifera. Marine Micropaleontology 6, 483-497.

Graniero, L.E., Grossman, E.L., Robbins, J.A., Morales, J., Thompson, R., O’dea, A., 2016. Gastropod shell $\delta^{13} \mathrm{C}$ values as proxies for $\delta^{13} \mathrm{C}_{\text {DIC }}$ in tropical waters. Palaeogeog., Palaeoclim., Palaeoecol. (in preparation).

Grossman, E.L., 1984. Stable isotope fractionation in live benthic foraminifera from the southern California borderland. Palaeogeogr., Palaeoclimatol., Palaeoecol. 47, 301-327. 
Grossman, E.L., 1987. Stable isotopes in modern benthic foraminifera: a study of vital effect. Journal of Foraminiferal Research 17, 48-61.

Grossman, E.L., 2012. Applying Oxygen Isotope Paleothermometry in Deep Time. In: Ivany, L.C., Huber, B.T. (Eds.), Reconstructing Earth's Deep-Time Climate - The State of the Art in 2012. Paleontological Society Papers 18, Paleontological Society, 39-67.

Grossman, E.L., Ku, T.-L., 1986. Oxygen and carbon isotope fractionation in biogenic aragonite: temperature effects. Chemical Geology (Isotope Geoscience Section) 59, 59-74.

Guzmán, H.M., Barnes, P.A.G., Lovelock, C.E., Feller, I.C., 2005. A site description of the CARICOMP mangrove, seagrass and coral reef sites in Bocas del Toro, Panama. Caribbean Journal of Science 41, 430-440.

Hamilton, C.P., Spero, H.J., Bijma, J., Lea, D.W., 2008. Geochemical investigation of gametogenic calcite addition in the planktonic foraminifera Orbulina universa. Marine Micropaleontology 68, 256-267.

Haug, G.H., Tiedemann, R., Zahn, R., Ravelo, A.C., 2001. Role of Panama uplift on oceanic freshwater balance. Geology 29, 207-210.

Havach, S.M., Collins, L.S., 1997. The distribution of Recent benthic foraminifera across habitats of Bocas del Toro, Caribbean Panama. Journal of Foraminiferal Research 27, $232-249$.

Ingram, B.L., Conrad, M.E., Ingle, J.C., Jr., 1996a. Stable isotope salinity systematics in estuarine waters and carbonates: San Francisco Bay. Geochimica et Cosmochimica Acta $60,455-467$.

Ingram, B.L., Ingle, J.C., Jr., Conrad, M.E., 1996b. Stable isotope record of late Holocene 
salinity and river discharge in San Francisco Bay, California. Earth Planet. Sci. Lett. 141, $237-247$.

Jackson, J.B.C., Jung, P., Coates, A.G., Collins, L.S., 1993. Diversity and extinction of tropical American molluscs and emergence of the Isthmus of Panama. Science 260, 1624-1626.

Jackson, J.B.C., Coates, A.G., Budd, A.F. (Eds.), 1996. Environmental and Biological Change in Neogene and Quaternary Tropical America. U. Chicago Press, 425 pp.

Kauffman, K.W., Thompson, R.C., 2005. Water temperature variation and the meteorological and hydrographic environment of Bocas del Toro, Panama. Caribbean Journal of Science $41,392-413$.

Keigwin, L.D., 1982. Isotopic paleoceanography of the Caribbean and East Pacific: role of Panama uplift in late Neogene time. Science 217, 350-353.

Kroopnick, P., 1985. The distribution of ${ }^{13} \mathrm{C}$ of $\Sigma \mathrm{CO}_{2}$ in the world oceans. Deep Sea Research Part A. Oceanographic Research Papers 32, 57-84.

Lea, D.W., Pak, D.K., Spero, H.J., 2000. Climate impact of late quaternary equatorial Pacific sea surface temperature variations. Science 289, 1719-1724.

Lear, C.H., Elderfield, H., Wilson, P.A., 2000. Cenozoic deep-sea temperatures and global ice volumes from $\mathrm{Mg} / \mathrm{Ca}$ in benthic foraminiferal calcite. Science 287, 269-272.

Lohmann, G.P., 1995. A model for variation in the chemistry of planktonic-foraminifera due to secondary calcification and selective dissolution. Paleoceanography 10, 445-457.

Loubere, P., Meyers, P., Gary, A., 1995. Benthic foraminiferal microhabitat selection, carbon isotope values, and association with larger animals: a test with Uvigerina peregrina. Journal of Foraminiferal Research 25, 83-95. 
Loubere, P., Jacobsen, B., Kristensen, D.K., Husum, K., Jernas, P., Richaud, M., 2011. The structure of benthic environments and the paleochemical record of foraminifera. DeepSea Res. Part I-Oceanogr. Res. Pap. 58, 535-545.

Lutze, G.F., Thiel, H., 1989. Cibicidoides wuellerstorfi and Planulina ariminensis, elevated epibenthic foraminifera. Journal of Foraminiferal Research 19, 153-158.

Mackensen, A., Hubberten, H.-W., Bickert, T., Fischer, G. Futterer, D.K., 1993. The $\delta^{13}$ C in benthic foraminiferal tests of Fontbotia wuellerstorfi (Schwager) relative to the $\delta^{13} \mathrm{C}$ of dissolved inorganic carbon in southern ocean deep water: implications for glacial ocean circulation models. Paleoceanography 8, 587-610.

McCorkle, D.C., Keigwin, L.D., 1994. Depth profiles of $\delta^{13} \mathrm{C}$ in bottom water and core-top $C$. wuellerstorfi on the Ontong-Java Plateau and Emperor Seamounts. Paleoceanography 9, 197-208.

McCorkle, D.C., Keigwin, L.D., Corliss, B.H., Emerson, S.R., 1990. The influence of microhabitats on the carbon isotopic composition of deep-sea benthic foraminifera. Paleoceanography 5, 161-185.

McCorkle, D.C., Corliss, B.H., Farnham, C.A., 1997. Vertical distributions and stable isotopic compositions of live (stained) benthic foraminifera from the North Carolina and California continental margins. Deep-Sea Res. Part I-Oceanogr. Res. Pap. 44, 983-1024.

van Morkhoven, F.P.C.M., Berggren, W.A., Edwards, A.S., 1986. Cenozoic Cosmopolitan Deep-water Benthic Foraminifera. Bulletin des Centres de Recherches ExplorationProduction Elf-Aquitaine, Memoir 11, Pau, 421 pp.

O'Dea, A., Jackson, J.B.C., Fortunato, H., Smith, J.T., D'Croz, L., Johnson, K.G., Todd, J.A., 
2007. Environmental change preceded Caribbean extinction by 2 million years. Proc. Natl. Acad. Sci. U.S.A. 104, 5501-5506.

Poag, C.W., 1981. Ecologic Atlas of Benthic Foraminifera of the Gulf of Mexico. Hutchinson Ross Pub. Co., 175 pp.

Reinhardt, E.G., Fitton, R.J., Schwarcz, H.P., 2003. Isotopic (Sr, O, C) indicators of salinity and taphonomy in marginal marine systems. Journal of Foraminiferal Research 33, 262-272.

Robbins, J.A., Tao, K., Grossman, E.L., O’Dea, A., 2012. Exploring the delayed overturn in Caribbean fauna using gastropod stable-isotope profiles to quantify seasonal upwelling and freshening of coastal waters. Geol. Soc. Am. Abstracts with Programs 44, 164.

Rodríguez, E., Almanza, R., Alvarado, R., 1993. Situación biofísica y ambiental de la Provincia de Bocas del Toro. In: Heckadon Moreno, S. (Ed.), Agenda Ecologia y Social para Bocas del Toro. Impresora Continental, S.A., 55-72.

Romanek, C.S., Grossman, E.L., Morse, J.W., 1992. Carbon isotope fractionation in synthetic aragonite and calcite - Effects of temperature and precipitation rate. Geochimica et Cosmochimica Acta 56, 419-430.

Schiffelbein, P., Hills, S., 1984. Direct assessment of stable isotope variability in planktonic foraminifera populations, Palaeogeogr., Palaeoclimatol., Palaeoecol. 48, 197-213. Shackleton, N.J., 1973. Attainment of isotopic equilibrium between ocean water and the benthonic foraminifera genus Uvigerina: isotopic changes in the ocean during the last glacial. In: Les Méthodes Quantitatives d'étude des Variations du Climat au Cours du Pléistocène. Colloques Internationaux du C.N.R.S. 219, 203-209.

Shackleton, N.J., 1977. Carbon-13 in Uvigerina: tropical rainforest history and the equatorial 
Pacific carbonate dissolution cycles. In: Andersen, N.R., Malahoff, A. (Eds.), The Fate of Fossil Fuel $\mathrm{CO}_{2}$ in the Oceans. Plenum Pr., NY, 401-428.

Shackleton, N.J., Opdyke, N.D., 1973. Oxygen isotope and palaeomagnetic stratigraphy of equatorial Pacific core V28-238: Oxygen isotope temperatures and ice volumes on a $10^{5}$ year and $10^{6}$ year scale. Quaternary Research 3, 39-55.

Smith, C.J., Collins, L.S., Hayek, L.-A. 2013. Biogeographic effects of the closing Central American Seaway on benthic foraminifera of Venezuela. Bull. Mar. Sci., Spec. Iss. Environmental, Ecological and Evolutionary Change in Seas Across the Isthmus of Panama, O’Dea, A., Collins, L.S. (Eds.), 89, 921-936.

Smith, P.B., Emiliani, C., 1968. Oxygen-isotope analysis of Recent tropical Pacific benthonic foraminifera. Science 160, 1335--1336.

Spero, H.J., 1988. An ultrastructural examination of chamber morphogenesis and biomineralization in the planktonic foraminiferan Orbulina universa. Marine Biology 99, 9-20.

Spero, H.J., DeNiro, M.J., 1987. The influence of symbiont photosynthesis on the $\delta^{18} \mathrm{O}$ and $\delta^{13} \mathrm{C}$ values of planktonic foraminiferal shell calcite. Symbiosis 4, 213-228.

Spero, H.J., Lerche, I., Williams, D.F., 1991. Opening the carbon isotope "vital effect" black box, 2. Quantitative model for interpreting foraminiferal carbon isotope data. Paleoceanography 6, 639-655.

Spero, H.J., Williams, D.F., 1988. Extracting environmental information from planktonic foraminiferal $\delta^{13} \mathrm{C}$. Nature $335,717-719$.

SYSTAT for Windows. Statistics, Version 5 Edition, 1992. SYSTAT, Inc., Evanston, Illinois, 
$750 \mathrm{pp}$.

Tao, K., Robbins, J.A., Grossman, E.L., O'Dea, A., 2013. Quantifying upwelling and freshening in nearshore tropical environments using stable isotopes in modern Tropical American mollusks. Bull. Mar. Sci. 89, 815-835.

Teranes, J.L., Geary, D.H., Bemis, B.E., 1996. The oxygen isotopic record of seasonality in Neogene bivalves from the Central American isthmus. In: Jackson, J.B.C., Coates, A.G., Budd, A.F. (Eds.), Environmental and Biological Change in Neogene and Quaternary Tropical America, Univ. Chicago Pr., 105-129.

Woodruff, F., Savin, S.M., 1989. Miocene deepwater oceanography. Paleoceanography 4, 87140.

Woodruff, F., Savin, S.M., Douglas, R.G., 1980. Biological fractionation of oxygen and carbon isotopes by Recent benthic foraminifera, Marine Micropaleontology 5, 3-11.

Zahn, R., Winn, K., Sarnthein, M., 1986. Benthic foraminiferal $\delta^{13} \mathrm{C}$ and accumulation rates of organic carbon: Uvigerina peregrina group and Cibicidoides wuellerstorfi. Paleoceanography 1, 27-42. 


\section{Figure 1}

Collins Figure 1,

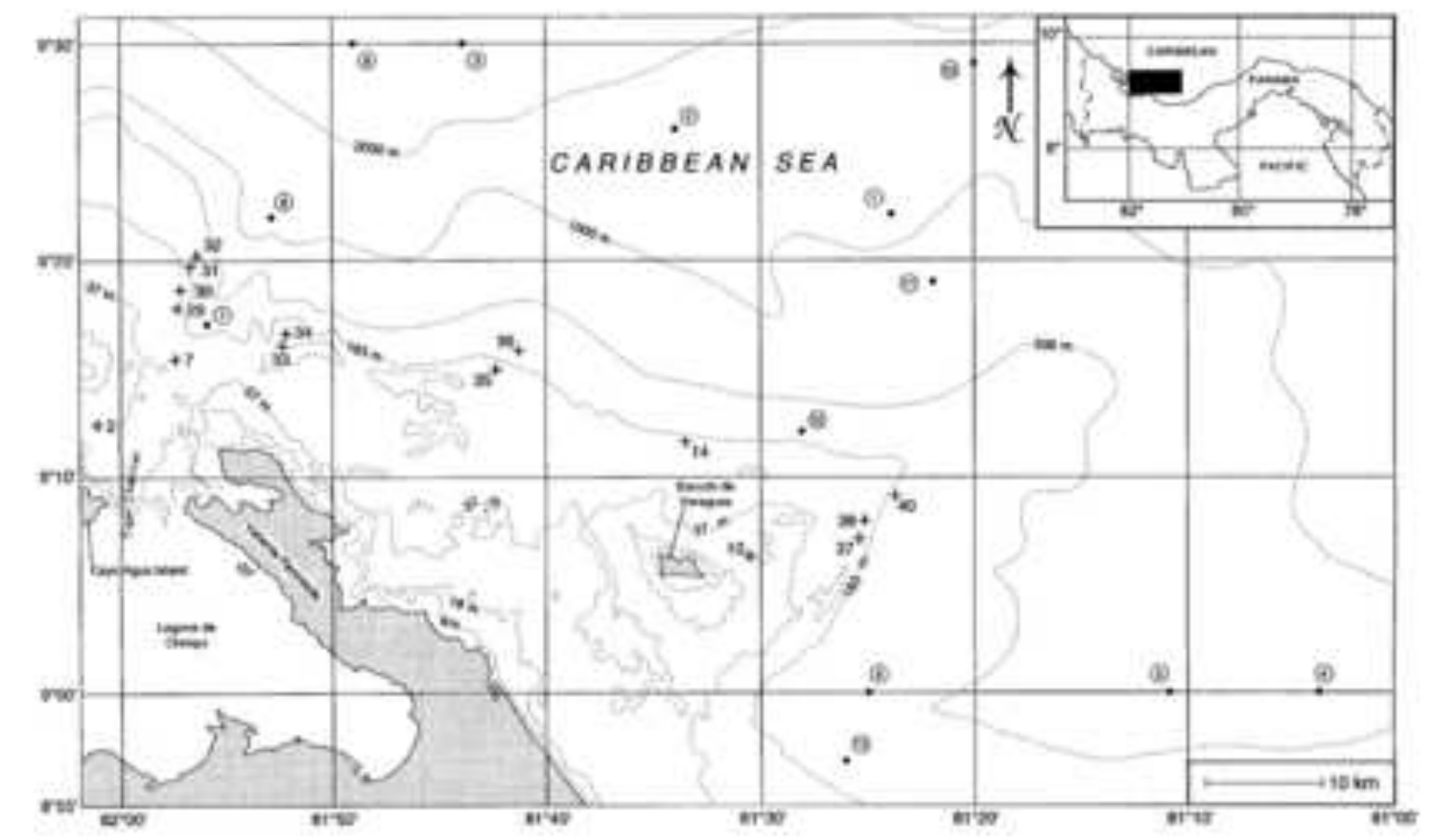

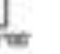

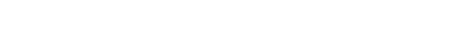

\section{2-column \\ 1,}

. 
Collins Figure 2,

2 columns

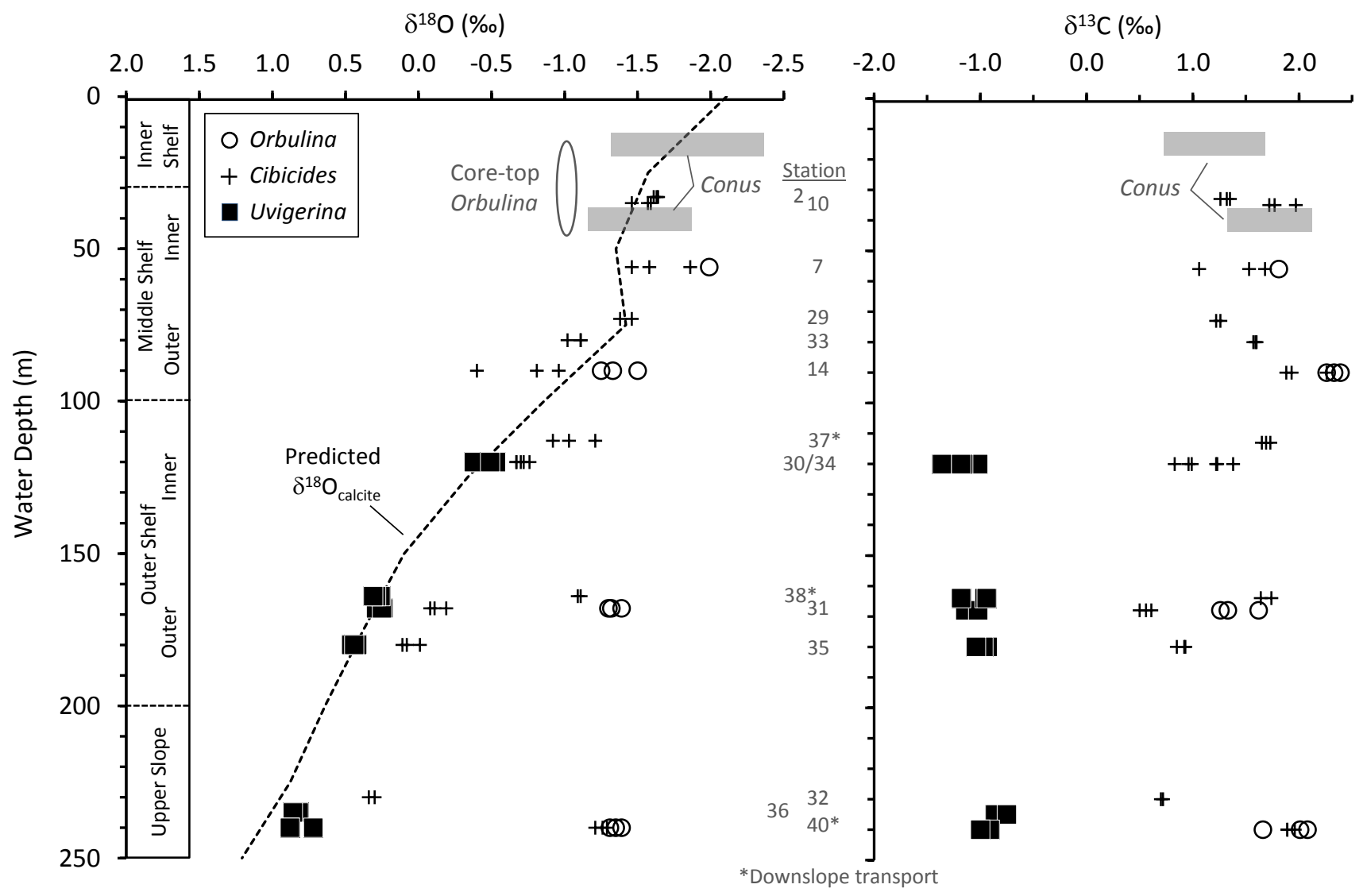




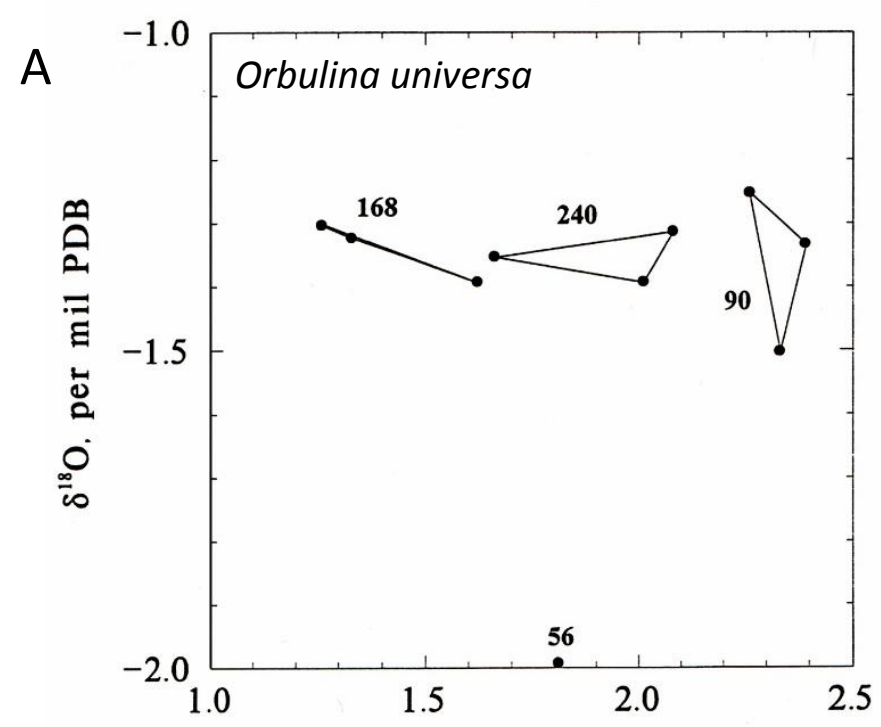

Collins Figure 3, single column
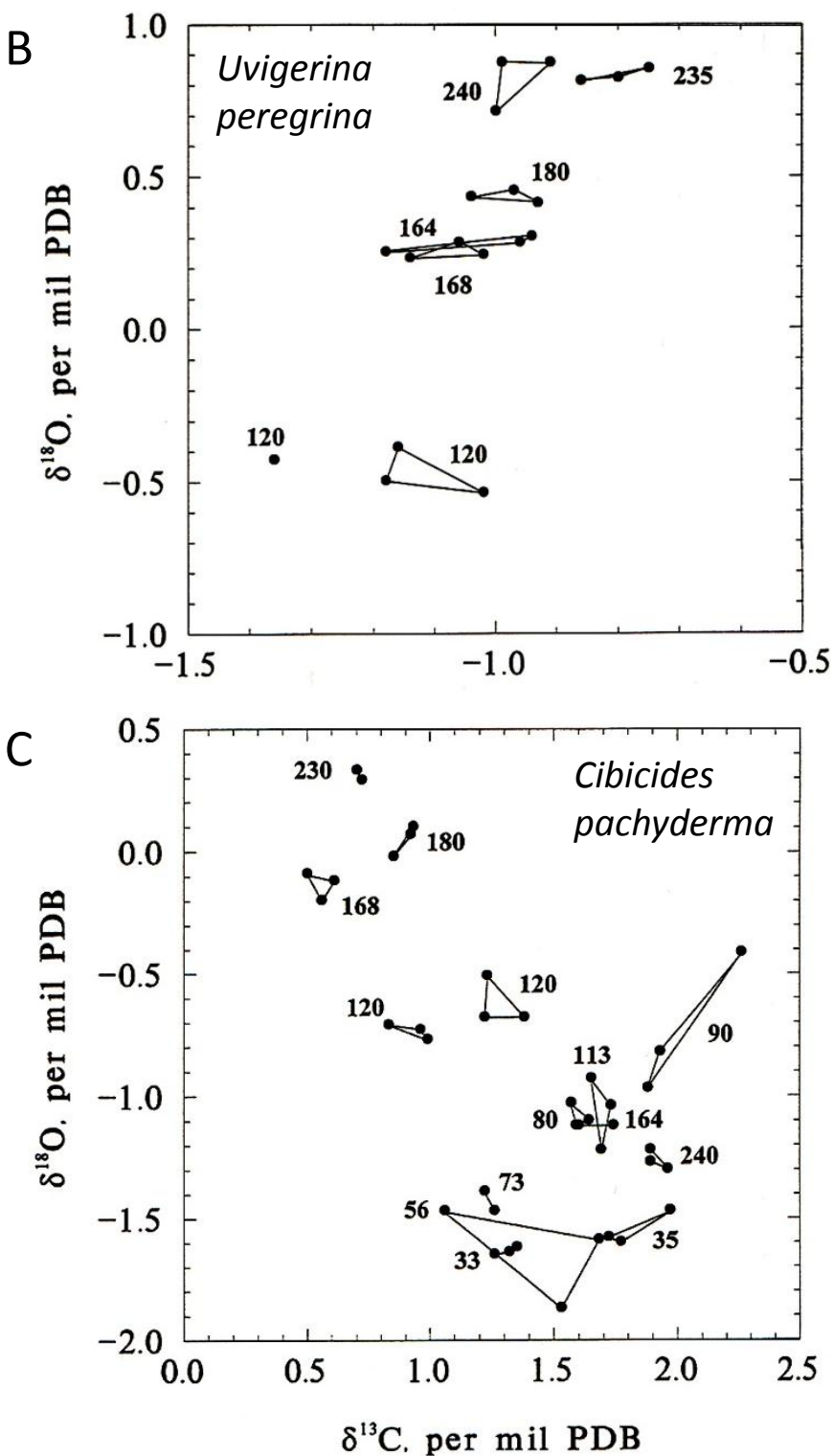
Collins Figure 4, single column

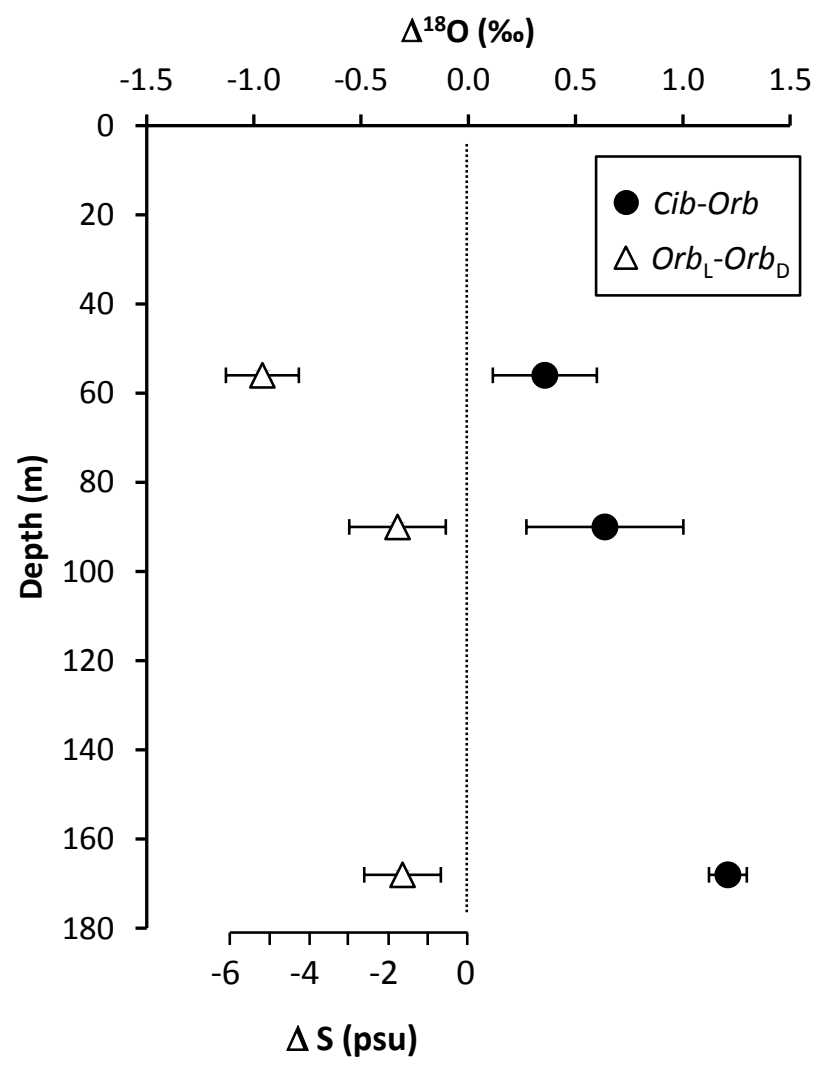


1. Study area (black rectangle, inset) in the archipelago of Bocas del Toro, Panama. $+=$ sample stations used in isotope analyses (Table 1). Circled numbers = U.S. Navy hydrographic stations (Table 2).

\section{Isotopic values for foraminifera from the Bocas del Toro archipelago, Panama. Shown for} each station are replicate values joined by lines, and water depths (m) of Table 1. A. $O$. universa data for open-ocean stations and the channel (56 m, combined replicates) where Tiger Channel and open-ocean waters meet. B. U. peregrina data for outer-shelf to slope stations. C. C. pachyderma data for middle-shelf to slope stations.

4. Oxygen isotope difference $\Delta^{18} \mathrm{O}$ between C. pachyderma and O. universa (Cib-Orb), and between local (Panama) and deep-sea $O$. universa $\left(O r b_{\mathrm{L}}-O r b_{\mathrm{D}}\right)$, for varying water depths. Deep-sea $\delta^{18} \mathrm{O}$ values for Orbulina are from the tropical Atlantic (Farmer et al., 2007). Error 
24 bars $=$ square roots of sums of squares of standard deviations, except for $56 \mathrm{~m}$ where the

25 standard deviation of C. pachyderma replicates is substituted because limited material

26 necessitated combining replicate samples of $O$. universa.

27 
Table 1

\begin{tabular}{cccc}
\hline Station \# & Latitude N & Long. W & Depth $(\mathrm{m})$ \\
\hline 2 & $9^{\circ} 12.6^{\prime}$ & $82^{\circ} 1.0^{\prime}$ & 33 \\
7 & $9^{\circ} 15.5^{\prime}$ & $81^{\circ} 57.6^{\prime}$ & 56 \\
10 & $9^{\circ} 6.4^{\prime}$ & $81^{\circ} 30.5^{\prime}$ & 35 \\
14 & $9^{\circ} 11.5^{\prime}$ & $81^{\circ} 33.5^{\prime}$ & 90 \\
29 & $9^{\circ} 17.9^{\circ}$ & $81^{\circ} 57.3^{\prime}$ & 73 \\
30 & $9^{\circ} 18.8^{\prime}$ & $81^{\circ} 57.1^{\circ}$ & 120 \\
31 & $9^{\circ} 19^{\circ} 8^{\prime}$ & $81^{\circ} 56.7^{\prime}$ & 168 \\
32 & $9^{\circ} 20.2^{\prime}$ & $81^{\circ} 56.3^{\prime}$ & 230 \\
33 & $9^{\circ} 16.0^{\prime}$ & $81^{\circ} 52.4^{\prime}$ & 80 \\
34 & $9^{\circ} 16.6^{\prime}$ & $81^{\circ} 52.3^{\prime}$ & 120 \\
35 & $9^{\circ} 15.0^{\prime}$ & $81^{\circ} 42.4^{\prime}$ & 180 \\
36 & $9^{\circ} 15.8^{\prime}$ & $81^{\circ} 41^{\circ} 3^{\prime}$ & 235 \\
37 & $9^{\circ} 7.7^{\prime}$ & $81^{\circ} 25.3^{\prime}$ & 113 \\
38 & $9^{\circ} 8.7^{\prime}$ & $81^{\circ} 24.8^{\prime}$ & 164 \\
40 & $9^{\circ} 9^{\circ} 2^{\prime}$ & $81^{\circ} 23.9^{\circ}$ & 240
\end{tabular}




\begin{tabular}{|c|c|c|c|c|c|c|c|}
\hline Depth (m) & $\begin{array}{c}\text { Mean T } \\
\left({ }^{\circ} \mathrm{C}\right)\end{array}$ & T range $\left({ }^{\circ} \mathrm{C}\right)$ & $S$ (psu) & $\begin{array}{c}\text { S range } \\
\text { (psu) }\end{array}$ & $\begin{array}{l}\delta^{18} \mathrm{O}_{\mathrm{w}}(\% \circ \\
\text { VSMOW) }\end{array}$ & $\begin{array}{c}\delta^{18} \mathrm{O}_{\mathrm{w}} \\
\text { (\%o"PDB") }\end{array}$ & $\begin{array}{c}\delta^{18} \mathrm{O} \text { (calc.) } \\
(\% \circ)\end{array}$ \\
\hline 0 & 28.26 & $27.35-29.00$ & 33.89 & $32.84-35.24$ & 0.69 & 0.42 & -2.11 \\
\hline 25 & 27.56 & $26.90-28.15$ & 35.97 & $35.62-36.08$ & 1.08 & 0.81 & -1.57 \\
\hline 50 & 26.67 & $25.96-28.10$ & 36.18 & $35.96-36.29$ & 1.12 & 0.85 & -1.35 \\
\hline 75 & 27.22 & $25.05-27.90$ & 36.41 & $36.23-36.52$ & 1.17 & 0.90 & -1.42 \\
\hline 100 & 24.64 & $23.49-25.82$ & 36.57 & $36.45-36.74$ & 1.20 & 0.93 & -0.86 \\
\hline 125 & 22.21 & $20.97-24.75$ & 36.62 & $36.43-36.76$ & 1.21 & 0.94 & -0.34 \\
\hline 150 & 20.19 & $19.01-22.44$ & 36.6 & $36.38-36.82$ & 1.20 & 0.93 & 0.10 \\
\hline 175 & 18.85 & $17.90-21.20$ & 36.49 & $36.33-36.72$ & 1.18 & 0.91 & 0.38 \\
\hline 200 & 17.57 & $16.62-19.38$ & 36.35 & $36.17-36.57$ & 1.16 & 0.89 & 0.64 \\
\hline 225 & 16.36 & $15.50-17.40$ & 36.13 & $36.00-36.36$ & 1.11 & 0.84 & 0.88 \\
\hline 250 & 14.79 & $14.31-15.34$ & 35.92 & $35.81-36.18$ & 1.07 & 0.80 & 1.21 \\
\hline
\end{tabular}




\begin{tabular}{|c|c|c|c|c|c|c|}
\hline Species & Station & Depth (m) & Replicate & $\delta^{18} \mathrm{O}$ & $\delta^{13} \mathrm{C}$ & Count $^{\mathrm{a}}$ \\
\hline O. universa & 7 & 56 & $a+b+c^{b}$ & -1.99 & 1.81 & 25 \\
\hline O. universa & 14 & 90 & a & -1.33 & 2.39 & 54 \\
\hline O. universa & 14 & 90 & $b$ & -1.50 & 2.33 & 73 \\
\hline O. universa & 14 & 90 & $d$ & -1.25 & 2.26 & 64 \\
\hline O. universa & 31 & 168 & a & -1.32 & 1.33 & 20 \\
\hline O. universa & 31 & 168 & $b$ & -1.30 & 1.26 & 29 \\
\hline O. universa & 31 & 168 & c & -1.39 & 1.62 & 27 \\
\hline O. universa & 40 & 240 & a & -1.39 & 2.01 & 90 \\
\hline O. universa & 40 & 240 & $b$ & -1.31 & 2.08 & 79 \\
\hline O. universa & 40 & 240 & $\mathrm{c}$ & -1.35 & 1.66 & 78 \\
\hline U. peregrina & 30 & 120 & $a$ & -0.42 & -1.36 & 138 \\
\hline U. peregrina & 31 & 168 & a & 0.29 & -1.06 & 118 \\
\hline U. peregrina & 31 & 168 & $b$ & 0.24 & -1.14 & 61 \\
\hline U. peregrina & 31 & 168 & c & 0.25 & -1.02 & 78 \\
\hline U. peregrina & 34 & 120 & a & -0.53 & -1.02 & 119 \\
\hline U. peregrina & 34 & 120 & $b$ & -0.38 & -1.16 & 128 \\
\hline U. peregrina & 34 & 120 & c & -0.49 & -1.18 & 122 \\
\hline U. peregrina & 35 & 180 & a & 0.42 & -0.93 & 155 \\
\hline U. peregrina & 35 & 180 & $b$ & 0.46 & -0.97 & 175 \\
\hline U. peregrina & 35 & 180 & c & 0.44 & -1.04 & 202 \\
\hline U. peregrina & 36 & 235 & a & 0.83 & -0.80 & 212 \\
\hline U. peregrina & 36 & 235 & $b$ & 0.82 & -0.86 & 189 \\
\hline U. peregrina & 36 & 235 & c & 0.86 & -0.75 & 196 \\
\hline U. peregrina & 38 & 164 & a & 0.26 & -1.18 & 68 \\
\hline U. peregrina & 38 & 164 & $b$ & 0.29 & -0.96 & 152 \\
\hline U. peregrina & 38 & 164 & c & 0.31 & -0.94 & 153 \\
\hline U. peregrina & 40 & 240 & a & 0.88 & -0.99 & 133 \\
\hline U. peregrina & 40 & 240 & $b$ & 0.88 & -0.91 & 108 \\
\hline U. peregrina & 40 & 240 & c & 0.72 & -1.00 & 175 \\
\hline C. pachyderma & 2 & 33 & $a$ & -1.63 & 1.32 & 172 \\
\hline C. pachyderma & 2 & 33 & $b$ & -1.61 & 1.35 & 172 \\
\hline C. pachyderma & 2 & 33 & c & -1.64 & 1.26 & 164 \\
\hline C. pachyderma & 7 & 56 & a & -1.58 & 1.68 & 71 \\
\hline C. pachyderma & 7 & 56 & $b$ & -1.86 & 1.53 & 38 \\
\hline C. pachyderma & 7 & 56 & c & -1.46 & 1.06 & 21 \\
\hline C. pachyderma & 10 & 35 & $a$ & -1.59 & 1.77 & 73 \\
\hline C. pachyderma & 10 & 35 & $b$ & -1.57 & 1.72 & 69 \\
\hline C. pachyderma & 10 & 35 & c & -1.46 & 1.97 & 42 \\
\hline C. pachyderma & 14 & 90 & a & -0.96 & 1.88 & 158 \\
\hline C. pachyderma & 14 & 90 & $b$ & -0.81 & 1.93 & 165 \\
\hline
\end{tabular}


Table 3,

continued

\begin{tabular}{|c|c|c|c|c|c|c|}
\hline C. pachyderma & 14 & 90 & $d$ & -0.40 & 2.26 & 182 \\
\hline C. pachyderma & 29 & 73 & a & -1.38 & 1.22 & 129 \\
\hline C. pachyderma & 29 & 73 & $b$ & -1.46 & 1.26 & 101 \\
\hline C. pachyderma & 30 & 120 & a & -0.70 & 0.83 & 127 \\
\hline C. pachyderma & 30 & 120 & $b$ & -0.76 & 0.99 & 65 \\
\hline C. pachyderma & 30 & 120 & c & -0.72 & 0.96 & 100 \\
\hline C. pachyderma & 31 & 168 & $\mathrm{a}$ & -0.19 & 0.56 & 243 \\
\hline C. pachyderma & 31 & 168 & $b$ & -0.08 & 0.50 & 150 \\
\hline C. pachyderma & 31 & 168 & c & -0.11 & 0.61 & 120 \\
\hline C. pachyderma & 32 & 230 & a & 0.34 & 0.70 & 9 \\
\hline C. pachyderma & 32 & 230 & $b$ & 0.30 & 0.72 & 16 \\
\hline C. pachyderma & 33 & 80 & $\mathrm{a}$ & -1.11 & 1.60 & 179 \\
\hline C. pachyderma & 33 & 80 & $b$ & -1.11 & 1.59 & 175 \\
\hline C. pachyderma & 33 & 80 & c & -1.02 & 1.57 & 151 \\
\hline C. pachyderma & 34 & 120 & $\mathrm{a}$ & -0.67 & 1.22 & 129 \\
\hline C. pachyderma & 34 & 120 & $b$ & -0.50 & 1.23 & 114 \\
\hline C. pachyderma & 34 & 120 & c & -0.67 & 1.38 & 167 \\
\hline C. pachyderma & 35 & 180 & $a$ & 0.11 & 0.93 & 117 \\
\hline C. pachyderma & 35 & 180 & $b$ & -0.01 & 0.85 & 160 \\
\hline C. pachyderma & 35 & 180 & c & 0.08 & 0.92 & 156 \\
\hline C. pachyderma & 37 & 113 & $a$ & -0.92 & 1.65 & 150 \\
\hline C. pachyderma & 37 & 113 & $b$ & -1.21 & 1.69 & 125 \\
\hline C. pachyderma & 37 & 113 & c & -1.03 & 1.73 & 152 \\
\hline C. pachyderma & 38 & 164 & $b$ & -1.09 & 1.64 & 152 \\
\hline C. pachyderma & 38 & 164 & c & -1.11 & 1.74 & 150 \\
\hline C. pachyderma & 40 & 240 & a & -1.26 & 1.89 & 150 \\
\hline C. pachyderma & 40 & 240 & $b$ & -1.21 & 1.89 & 152 \\
\hline C. pachyderma & 40 & 240 & c & -1.29 & 1.96 & 190 \\
\hline
\end{tabular}

${ }^{a}$ Number of specimens before washing, which removed $~ 39-91 \%$ of calcite.

${ }^{\mathrm{b}}$ Replicates combined because of insufficient sample sizes. 


\section{Table Captions}

TABLE 1. Sample locations and water depths of Figure 1

TABLE 2. Summary of data from hydrographic stations of Figure 1, collected in November (stations 1-3), May to June (stations 4-12), and April (station 13)

TABLE 3. Stable isotope values (\%o relative to PDB) of replicate samples 